\title{
PENGARUH KOMPENSASI DAN LINGKUNGAN KERJA TERHADAP KINERJA KARYAWAN PT. MOPOLI RAYA WILAYAH TIMUR ACEH TAMIANG
}

\author{
Syardiansah $^{1}$, Meutia Dewi ${ }^{1}$, Iswari Puji Lestari ${ }^{1}$ \\ ${ }^{1}$ Manajemen, Fakultas Ekonomi, Universitas Samudra, Indonesia \\ Email: syardiansah@unsam@ac.id
}

\begin{abstract}
Abstrak
Penelitian ini bertujuan untuk mengetahui pengaruh kompensasi dan lingkungan kerja terhadap kinerja karyawan PT. Mopoli Raya Wilayah Timur Aceh Tamiang. Penelitian ini merupakan jenis penelitian kuantitatif dengan pengambilan sampel menggunakan metode nonprobability sampling yaitu dengan cara sampling jenuh dan diperoleh sampel sebanyak 33 responden. Metode analisis data yang digunakan adalah analisis regresi linier berganda. Uji hipotesis yang dilakukan melalui uji parsial (uji t), uji simultan (uji F), dan uji koefisien determinasi (R2). Berdasarkan analisis data diperoleh persamaan regresi yaitu $\mathrm{Y}$ $=2,883+0,293 \mathrm{X} 1+0,025 \mathrm{X} 2$. Hasil uji t diperoleh pada kompensasi $\mathrm{t}$ sig sebesar 0,008 $<0,05$, maka hipotesis diterima yang berarti bahwa kompensasi berpengaruh secara signifikan terhadap kinerja karyawan. Kemudian hasil uji t pada lingkungan kerja t sig sebesar 0,881 >0,05, maka hipotesis ditolak yang berarti bahwa lingkungan kerja berpengaruh tidak signifikan terhadap kinerja karyawan. Hasil uji $\mathrm{F}$ diperoleh $\mathrm{F}$ sig sebesar $0,023<0,05$, maka hipotesis diterima yang berarti bahwa kompensasi dan lingkungan kerja secara simultan berpengaruh signifikan terhadap kinerja karyawan. Koefisien determinasi (R2) diketahui bahwa variabel kompensasi dan lingkungan kerja mempengaruhi kinerja karyawan PT. Mopoli Raya Wilayah Timur Aceh Tamiang sebesar 22,3\% dan sisanya sebesar 77,7\% dipengaruhi oleh variabel lain yang tidak diteliti dalam penelitian ini.
\end{abstract}

Keywords: Kompensasi, Lingkungan Kerja, Kinerja 


\section{PENDAHULUAN}

Pertumbuhan perekonomian Indonesia yang tidak stabil dan persaingan yang semakin ketat dalam dunia usaha saat ini memberikan dampak negatif kepada para pelaku bisnis terutama bagi beberapa perusahaan, baik perusahaan besar maupun perusahaan kecil. Ketidakstabilan ekonomi mengakibatkan banyak perusahaan melakukan berbagai upaya untuk dapat mempertahankan agar usaha yang dijalankan tetap stabil dan bertahan di dunia bisnis Indonesia. Salah satu upaya yang banyak dilakukan oleh perusahaan yaitu dengan mengelola dan menggunakan sumber daya manusia dengan baik dan benar. Hal itu mengakibatkan perusahaan menuntut karyawan agar menciptakan kinerja yang efektif dan efisien semaksimal mungkin guna meminimalkan dampak yang terjadi akibat ketidakstabilan perekonomian Indonesia.

Karena pentingnya sumber daya manusia bagi kelangsungan hidup dan kemajuan perusahaan, sudah sewajarnya jika perusahaan harus dapat bersikap adil atas apa yang telah diberikan karyawan untuk perusahaan, karena setiap karyawan berhak mendapatkan penghargaan dan perlakuan yang adil dari pimpinan sebagai timbal balik atas jasa yang diberikan kepada perusahaan, dan karyawan dapat termotivasi untuk bekerja semaksimal mungkin.

Karyawan memberikan prestasi kerja yang baik untuk kemajuan perusahaan, sedangkan perusahaan memberikan kompensasi yang sesuai dengan prestasi kerja yang telah diberikan karyawan terhadap perusahaan. Besarnya kompensasi bagi mereka mencerminkan ukuran nilai karya mereka diantara karyawan itu sendiri. Jadi bila karyawan memandang kompensasi mereka tidak memadai, prestasi kerja, motivasi dan kepuasan kerja mereka biasa turun secara drastis.

Selain kompensasi, faktor lain yang perlu diperhatikan adalah lingkungan kerja, Lingkungan kerja menurut Sedarmayanti (2011:76) adalah keseluruhan alat perkakas dan bahan yang dihadapi, lingkungan sekitarnya dimana seseorang bekerja, metode kerjanya, serta pengaturan kerjanya baik sebagai perseorangan maupun sebagai kelompok.

Lingkungan kerja sangat berkaitan erat dengan tinggi rendahnya kepuasan karyawan, dan apabila lingkungan kerja baik, maka dapat memberikan pengaruh yang positif terhadap
NIAGAWAN Vol 7 No 3 November 2018

kinerja karyawan dan sebaliknya. Suatu kondisi kerja dikatakan baik atau sesuai apabila sumber daya manusia dapat melaksanakan kegiatan secara optimal, sehat, aman, dan nyaman. Kompensasi dan lingkungan kerja merupakan faktor yang berpengaruh terhadap kinerja karyawan.

Kinerja seorang karyawan merupakan hal yang bersifat individual, karena setiap karyawan mempunyai tingkat kemampuan yang berbeda-beda dalam mengerjakan tugasnya. Menurut Wibowo (2013:209), kinerja merupakan perilaku nyata yang ditampilkan setiap orang sebagai prestasi kerja yang dihasilkan oleh karyawan sesuai dengan perannya dalam perusahaan. Kinerja karyawan merupakan bagian yang cukup penting dalam pencapaian tujuan organisasi. Jika kinerja meningkat maka keberhasilan mencapai tujuan perusahaan semakin terbuka lebar, tetapi apabila kinerja menurun maka bisa mengakibatkan kemunduran bagi perusahaan dan perusahaan tidak dapat mempertahankan usahanya.

Seperti halnya yang terjadi pada perusahaan yang bergerak dalam sektor agroindustri PT. Mopoli Raya Wilayah Timur Aceh Tamiang ini, yang memiliki sebuah permasalahan mengenai hal yang menyangkut karyawan. Sesuai dengan visi perusahaan yaitu menjadi perusahaan yang berkinerja tinggi dan berkelanjutan dengan basis agribisnis yang kuat dikawasan regional serta salah satu misi perusahaan yaitu mengelola dan mengembangkan jajaran SDM secara profesional di bidang perkebunan yang bermanfaat bagi seluruh pemangku kepentingan maka sudah seharusnya kinerja karyawan yang optimal sangat dibutuhkan dalam mewujudkan visi dan misi perusahaan..

\section{TINJAUAN PUSTAKA}

\section{Kompensasi}

Kompensasi adalah semua pendapatan yang berbentuk uang, barang langsung atau tidak langsung yang diterima karyawan sebagai imbalan atas jasa yang diberikan kepada perusahaan. Kompensasi berbentuk uang maksudnya kompensasi dibayar dengan sejumlah uang kartal kepada karyawan bersangkutan dan kompensasi berbentuk barang artinya kompensasi dibayar dengan barang (Hasibuan, 2014:118).

Kompensasi adalah segala sesuatu yang diterima oleh karyawan sebagai balas jasa kerja 
mereka kepada perusahaan menurut Sedarmayanti (2011:239). Menurut Flippo dalam Samsudin (2010:187) kompensasi adalah harga untuk jasa yang diterima atau diberikan oleh orang lain bagi kepentingan seseorang atau badan hukum. Sedangkan menurut Panggabean dalam Sutrisno (2011:181) mengemukakan bahwa kompensasi dapat didefenisikan setiap bentuk penghargaan yang diberikan kepada karyawan sebagai balas jasa atas kontribusi yang mereka berikan kepada organisasi.

Sementara menurut Werther dan Davis dalam Hasibuan (2014:119) Kompensasi adalah apa yang seorang pekerja terima sebagai balasan dari pekerjaan yang diberikannya. Baik upah per jam ataupun gaji periodik didesain dan dikelola oleh bagian personalia. Tujuan kompensasi yang dikemukakan oleh Hasibuan (2014:121) adalah sebagai berikut:

1. Ikatan Kerja Sama

Dengan pemberian kompensasi terjalinlah ikatan kerja sama formal antara majikan dengan karyawan. Karyawan harus mengerjakan tugas-tugasnya dengan baik, sedangkan pengusaha/majikannya wajib membayar kompensasi sesuai dengan perjanjian yang disepakati.

2. Kepuasan Kerja

Dengan balas jasa, karyawan akan dapat memenuhi kebutuhan-kebutuhan fisik, status, sosial, dan egoistiknya sehingga memperoleh kepuasan kerja dari kompensasi yang diterimanya.

3. Pengadaan Efektif

Jika program kompensasi ditetapkan cukup besar, pengadaan karyawan yang qualified untuk perusahaan akan lebih mudah.

4. Motivasi

Jika balas jasa yang diberikan perusahaan untuk karyawan cukup besar, manajer akan lebih mudah memotivasi bawahannya agar menghasilkan

output yang lebih efektif dan efesien.

5. Stabilitas Karyawan

Dengan program kompensasi atas prinsip adil dan layak serta eksternal konsistensi yang kompentatif maka stabilitas karyawan lebih terjamin karena turn over relatif kecil.

6. Disiplin

Dengan pemberian balas jasa yang cukup besar maka disiplin karyawan semakin baik. Mereka akan menyadari serta mentaati peraturan-peraturan yang berlaku.

7. Pengaruh serikat buruh
NIAGAWAN Vol 7 No 3 November 2018

Dengan program kompensasi yang baik pengaruh serikat buruh dapat dihindarkan dan banyak karyawan akan berkonsentrasi pada pekerjaannya.

8. Pengaruh Pemerintah

Jika program kompensasi sesuai dengan undang-undang perburuhan yang berlaku (seperti batas upah minimum) maka intervasi pemerintah dapat dihindarkan.

Menurut Panggabean (2010:76), kompensasi dapat dibedakan menjadi dua, yaitu :

1. Kompensasi Langsung adalah kompensasi yang langsung dirasakan oleh penerimanya, yakni berupa gaji, tunjangan, insentif merupakan hak karyawan dan kewajiban perusahaan yang pasti.

a. Gaji adalah balas jasa yang dibayar secara periodik kepada karyawan tetap serta mempunyai jaminan yang pasti.

b. Tunjangan adalah kompensasi yang diberikan perusahaan kepada para karyawannya tersebut dianggap telah ikut berpartisipasi dengan baik dalam mencapai tujuan perusahaan.

c. Insentif adalah kompensasi yang diberikan kepada karyawan yang tertentu, karena keberhasilan prestasinya di atas standar.

2. Kompensasi tidak langsung adalah kompensasi yang tidak dapat dirasakan secara langsung oleh karyawan, yakni benefit dan services (tunjangan pelayanan). Benefit dan services adalah kompensasi tambahan (financial atau non financial) yang diberikan berdasarkan kebijaksanaan perusahaan terhadap semua karyawan dalam usaha meningkatkan kesejahteraan mereka.

Indikator kompensasi menurut Simamora (2009:442) yaitu:

1. Puas Terhadap Gaji

Hak yang diterima oleh karyawan karena kompensasinya terhadap perusahaan.

2. Puas Terhadap Fasilitas

Kompensasi yang diberikan kepada karyawan sebagai penunjang kelancaran untuk berkerja dan memotivasi karyawan agar semangat kerja.

3. Puas Terhadap Tunjangan

Kompensasi tambahan diberikan berdasarkan kebijakan perusahaan terhadap karyawan dalam usaha meningkatkan kesejahteraan karyawan. 


\section{Lingkungan Kerja}

Lingkungan kerja merupakan segala sesuatu yang ada disekitar para pekerja yang dapat mempengaruhi dirinya dalam menjalankan tugastugas yang diembankan (Nitisemito, 2009:43). Sutrisno (2011:118) mengungkapkan bahwa, lingkungan kerja adalah keseluruhan sarana dan prasarana kerja yang ada sekitar pegawai yang sedang melakukan pekerjaan yang dapat mepengaruhi pelaksanaan pekerjaan. Lingkungan kerja ini meliputi tempat bekerja, fasilitas dana alat bantu pekerjaan, kebersihaan, pencahayaan, ketenangan, termasuk juga termasuk juga hubungan kerja antara orang-orang yang ada ditempat tersebut.

Menurut Rivai (2009:165), lingkungan kerja adalah keseluruhan sarana dan prasarana yang ada disekitar karyawan yang sedang melakukan pekerjaan itu sendiri. Sementara Sunyoto (2012:43) menyatakan bahwa lingkungan kerja merupakan bagian komponen yang sangat penting bagi karyawan dalam bekerja. Lingkungan kerja yang baik atau kondisi kerja yang mampu memberikan motivasi untuk bekerja akan berpengaruh terhadap semangat karyawan dalam bekerja.

Sedangkan menurut Sedarmayanti (2011:76), lingkungan kerja adalah keseluruhan alat perkakas dan bahan yang dihadapi, lingkungan sekitarnya dimana seseorang bekerja, metode kerjanya, serta pengaturan kerjanya baik sebagai perseorangan maupun sebagai kelompok. Menurut Sedarmayanti (2009:21) menyatakan bahwa secara garis besar, jenis lingkungan kerja terbagi menjadi 2 (dua) yaitu :

1. Lingkungan Kerja Fisik

Lingkungan kerja fisik adalah semua keadaan berbentuk fisik yang terdapat di sekitar tempat kerja yang dapat mempengaruhi karyawan baik secara langsung maupun tidak langsung.

Lingkungan kerja fisik terbagi dalam dua kategori, yaitu :

a. Lingkungan yang langsung berhubungan dengan karyawan, seperti: pusat kerja, kursi, meja, dan sebagainya.

b. Lingkungan perantara atau lingkungan umum dapat juga disebut lingkungan kerja yang mempengaruhi kondisi manusia, misalnya: temperatur, kelembaban, sirkulasi udara, pencahayaan, kebisingan, getaran mekanis, bau tidak sedap, warna, dan lain - lain.

Untuk dapat memperkecil pengaruh lingkungan fisik terhadap karyawan, maka
NIAGAWAN Vol 7 No 3 November 2018

langkah pertama adalah harus mempelajari manusia, baik mengenai fisik dan tingkah lakunya maupun mengenai fisiknya, kemudian dijadikan sumber dasar sebagai dasar pemikiran lingkungan fisik yang sesuai.

2. Lingkungan Kerja Non Fisik

Lingkungan kerja non fisik adalah semua keadaan yang terjadi yang berkaitan dengan hubungan kerja, baik hubungan dengan atasan maupun hubungan dengan rekan kerja, ataupun hubungan dengan bawahan. Lingkungan kerja non fisik ini juga merupakan kelompok lingkungan kerja yang tidak bisa di abaikan.

Menurut Sedarmayanti (2009:21), faktorfaktor yang mempengaruhi lingkungan kerja yaitu :

1. Penerangan/Cahaya di Tempat Kerja

Cahaya atau penerangan sangat besar manfaatnya bagi pegawai guna mendapat keselamatan dan kelancaran kerja. Oleh sebab itu, perlu diperhatikan adanya penerangan (cahaya yang terang) tetapi tidak menyilaukan. Cahaya yang kurang jelas mengakibatkan penglihatan menjadi kurang jelas, pekerjaan akan berjalan lambat, banyak mengalami kesalahan, menyebabkan kurang efisien dalam melaksanakan pekerjaan, sehingga tujuan organisasi sulit dicapai.

2. Temperatur di Tempat Kerja

Dalam keadaan normal, tiap anggota tubuh manusia mempunyai temperatur berbeda. Tubuh manusia selalu berusaha untuk mempertahankan keadaan normal dengan suatu sistem tubuh yang sempurna sehingga dapat menyesuaikan diri dengan perubahan yang terjadi diluar tubuh. Akan tetapi, kemampuan menyesuaikan diri tersebut ada batasnya. Tubuh manusia masih dapat menyesuaikan dirinya dengan temperatur luar jika perubahan temperatur luar tubuh tidak lebih dari 20\% untuk kondisi panas dan 35\% untuk kondisi dingin, dari keadaan normal tubuh.

3. Kelembapan di Tempat Kerja

Kelembapan adalah banyaknya air yang terkandung dalam udara, dan biasanya dinyatakan dalam presentase. Kelembapan ini berhubungan atau dipengaruhi oleh temperatur kelembapan, kecepatan udara bergerak, dan radiasi panas dari udara tersebut akan memengaruhi keadaan tubuh manusia pada saat menerima atau melepaskan panas dari 
tubuhnya. Suatu keadaan dengan temperatur udara sangat panas dan kelembapan tinggi, akan menimbulkan pengurangan panas tubuh secara besar-besaran karena sistem penguapan. Pengaruh lain adalah makin cepatnya denyut jantung karena makin aktifnya peredaran darah untuk memenuhi kebutuhan oksigen. Selain itu, tubuh manusia selalu berusaha untuk mencapai keseimbangan antara panas tubuh dengan suhu di sekitarnya.

4. Sirkulasi Udara di Tempat Kerja

Oksigen merupakan gas yang dibutuhkan oleh makhluk hidup untuk menjaga kelangsungan hidup, yaitu untuk proses metabolisme. Udara di sekitar dikatakan kotor apabila kadar oksigen dalam udara tersebut telah berkurang dan bercampur dengan gas atau bau-bauan yang berbahaya bagi kesehatan tubuh. Udara yang kotor mengakibatkan sesak napas. Hal ini tidak boleh dibiarkan berlangsung terlalu lama, karena akan memengaruhi kesehatan tubuh dan akan mempercepat proses kelelahan. Sumber utama adanya udara segar adalah adanya tanaman disekitar tempat kerja. Tanaman merupakan penghasil oksigen yang dibutuhkan oleh manusia. Dengan cukupnya oksigen di sekitar tempat kerja dan pengaruh psikologis adanya tanaman di sekitar tempat kerja, akan memberikan kesejukan dan kesegaran pada jasmani. Rasa sejuk dan segar selama bekerja akan membantu mempercepat pemulihan tubuh akibat lelah setelah bekerja.

5. Kebisingan di Tempat Kerja

Salah satu polusi yang cukup menyibukkan para pakar untuk mengatasinya adalah kebisingan, bunyi yang tidak dikehendaki telinga karena dapat mengganggu ketenangan bekerja, merusak pendengaran, dan menimbulkan kesalahan komunikasi. Bahkan, menurut suatu penelitian, kebisingan yang serius bisa menyebabkan kematian. Karena pekerjaan membutuhkan konsentrasi, suara bising hendaknya dihindarkan agar pelaksanaan pekerjaan dapat dilakukan dengan efisien sehingga produktivitas kerja meningkat.

6. Getaran Mekanis di Tempat Kerja

Getaran mekanis artinya getaran yang ditimbulkan oleh alat mekanis yang sebagian getaran ini sampai ke tubuh karyawan dan dapat menimbulkan akibat yang tidak diinginkan. Getaran mekanis pada umumnya sangat mengganggu tubuh karena ketidakteraturan, baik dalam intensitas
NIAGAWAN Vol 7 No 3 November 2018 maupun frekuensi. Secara umum, getaran mekanis dapat mengganggu tubuh dalam hal konsentrasi bekerja, datangnya kelelahan, timbulnya beberapa penyakit diantaranya gangguan terhadap mata, syaraf, peredaran darah, otot, tulang, dll.

7. Bau Tidak Sedap

Adanya bau tidak sedap di sekitar tempat kerja dapat dianggap sebagai pencemaran, karena dapat mengganggu konsentrasi bekerja. Baubauan yang terjadi terus-menerus dapat memengaruhi kepekaan penciuman. Pemakaian AC yang tepat merupakan salah satu cara yang dapat digunakan untuk menghilangkan bau-bauan yang mengganggu di sekitar tempat kerja.

8. Dekorasi di Tempat Kerja

Dekorasi ada hubungannya dengan tata warna yang baik, oleh karena itu dekorasi tidak hanya berkaitan dengan hasil ruang kerja tetapi juga dengan cara mengatur tata letak, tata warna, perlengkapan, dan hal lainnya untuk bekerja.

9. Musik di Tempat Kerja

Menurut para pakar, musik yang bernada lembut sesuai dengan suasana, waktu, dan tempat dapat membangkitkan dan merangsang pegawai untuk bekerja. Oleh karena itu, lagulagu perlu di pilih dengan selektif untuk diperdengarkan di tempat kerja. Tidak sesuainya musik yang diperdengarkan di tempat kerja akan mengganggu konsentrasi kerja.

10. Keamanan di Tempat Kerja

Guna menjaga tempat dan kondisi lingkungan kerja tetap dalam keadaan aman, perlu diperhatikan keamanan dalam bekerja. Oleh karena itu, faktor keamanan perlu diwujudkan keberadaannya. Salah satu upaya untuk menjaga keamanan di tempat kerja, dapat memanfaatkan tenaga Satuan Petugas Keamanan (SATPAM).

\section{Kinerja}

Menurut Sutrisno (2012:99) kinerja secara umum diartikan sebagai hubungan antara keluaran (barang-barang atau jasa) dan masukan (tenaga kerja, bahan, uang). Kinerja adalah ukuran efisiensi produktif; suatu perbandingan antara hasil keluaran dan masukan. Masukan sering dibatasi dengan tenaga kerja, sedangkan keluaran diukur dalam kesatuan fisik, bentuk, dan nilai. Sementara kinerja menurut Wibowo (2013:209), kinerja merupakan perilaku nyata 
yang ditampilkan setiap orang sebagai prestasi kerja yang dihasilkan oleh karyawan sesuai dengan perannya dalam perusahaan. Dan Menurut Sedarmayanti (2011:260) bahwa kinerja merupakan terjemahan dari performance yang berarti hasil kerja dari seorag pekerja, sebuah proses manajemen atau sebuah organisasi secara keseluruhan, dimana hasil kerja tersebut harus dapat ditunjukkan buktinya secara konkrit dan dapat diukur.

Kinerja adalah hasil pekerjaan yang dicapai seseorang atau kelompok seperti standar hasil kerja, target yang ditentukan selama periode tertentu yang berpedoman pada norma, standar operasional prosedur, kriteria dan fungsi yang telah ditetapkan atau yang berlaku dalam perusahaan (Bangun, 2012:231). Menurut Bangun (2012:233), penilaian kinerja seorang karyawan, standar pekerjaannya harus dapat diukur dan dipahami secara jelas melalui:

\section{Jumlah Pekerjaan}

Jumlah pekerjaan yang dihasilkan individu atau kelompok sebagai persyaratan yang menjadi standar pekerjaan. Setiap pekerjaan memiliki persyaratan yang berbeda sehingga menuntut karyawan harus memenuhi persyaratan tersebut baik pengetahuan, keterampilan, maupun kemampuan yang sesuai.

2. Kualitas Pekerjaan

Setiap karyawan dalam perusahaan harus memenuhi persyaratan tertentu untuk dapat menghasilkan pekerjaan sesuai kualitas yang dituntut suatu pekerjaan tertentu. Setiap pekerjaan memiliki standar kualitas tertentu yang harus disesuaikan oleh karyawan untuk dapat mngerjakannya sesuai ketentuan. Karyawan memliki kinerja baik bila dapat menghasilkan pekerjaan sesuai persyaratan kualitas yang dituntut pekerjaan tersebut.

3. Ketepatan Waktu

Jenis pekerjaan tertentu harus diselesaikan tepat waktu, karena memiliki ketergantungan atas pekerjaan lainnya. Jadi apabila pekerjaan pada suatu bagian tertentu tidak selesai tepat waktu akan menghambat pekerjaan pada bagian lain, sehingga mempengaruhi kuantitas dan kualitas hasil pekerjaan.

4. Kehadiran

Ada tipe pekerjaan yang menuntut kehadiran karyawan selama delapan jam sehari untuk lima hari kerja seminggu. Kinerja karyawan ditentukan oleh tingkat kehadiran karyawan dalam mengerjakannya.
NIAGAWAN Vol 7 No 3 November 2018

\section{Kemampuan Kerja Sama}

Untuk jenis pekerjaan tertentu mungkin harus disesuaikan oleh dua orang karyawan atau lebih, sehingga kerja sama antar karyawan sangat dibutuhkan..

\section{METODE PENELITIAN \\ Lokasi dan Waktu Penelitian}

Penelitian ini dilakukan pada PT. Mopoli Raya Wilayah Timur Aceh Tamiang yang terletak di PKS Gedong Biara Kabupaten Aceh Tamiang. Penelitian ini dilaksanakan selama 6 (enam) bulan dari bulan Mei sampai bulan Oktober 2018.

\section{Populasi dan Sampel}

Populasi dalam penelitian ini adalah seluruh karyawan PT. Mopoli Raya Wilayah Timur Aceh Tamiang baik karyawan pimpinan maupun karyawan pelaksana di PT. Mopoli Raya Wilayah Timur Aceh Tamiang yang berjumlah 33 karyawan yang berada di kantor. Pengambilan sampel menggunakan metode nonprobability sampling yaitu dengan cara sampling jenuh. Menurut Sugiyono (2016:85), teknik sampling jenuh adalah teknik penentuan sampel bila semua anggota populasi digunakan sebagai sampel. Oleh karena itu, jumlah sampel dalam penelitian ini berjumlah 33 responden.

\section{Definisi Operasional}

a. Kompensasi adalah segala sesuatu yang diterima karyawan PT. Mopoli Raya sebagai balas jasa dari perusahaan terhadap kinerjanya baik materi maupun non materi. Dengan indikator: Puas Terhadap Gaji, Puas Terhadap Fasilitas dan Puas Terhadap Tunjangan

b. Lingkungan kerja adalah segala sesuatu yang berada di sekitar karyawan PT. Mopoli Raya dan memiliki pengaruh yang cukup besar bagi karyawan dalam menjalankan tugastugas yang dibebankan kepada karyawan. Dimana indikatornya adalah Penerangan di Tempat Kerja, Temperatur di Tempat Kerja, Kelembapan di Tempat Kerja, Sirkulasi Udara di Tempat Kerja, Kebisingan di Tempat Kerja, Getaran Mekanis di Tempat Kerja, Bau Tidak Sedap, Dekorasi di Tempat Kerja, Musik di Tempat Kerja dan Keamanan di Tempat Kerja

c. Kinerja adalah Hasil kerja secara kualitas dan kuantitas yang tercapai oleh seluruh karyawan PT. Mopoli Raya dalam melaksanakan tugasnya sesuai dengan 
tanggung jawab yang diberikan kepadanya. Dimana indikatornya adalah Jumlah pekerjaan, Kualitas pekerjaan, Ketepatan waktu, Kehadiran, Kemampuan kerja sama

\section{Teknik Analisis Data}

\section{Perhitungan Regresi Linear Berganda}

Untuk mengetahui pengaruh $X_{1}$ dan $X_{2}$ terhadap $\mathrm{Y}$ digunakan persamaan regresi linear berganda dengan rumus:

$$
\mathrm{Y}=\mathrm{a}+\mathrm{b}_{1} \mathrm{X}_{1}+\mathrm{b}_{2} \mathrm{X}_{2}
$$

Dimana $\mathrm{Y}=$ Kinerja Karyawan

$$
\begin{aligned}
& \mathrm{X}_{1}=\text { Kompensasi } \\
& \mathrm{X}_{2}=\text { Lingkungan Kerja }
\end{aligned}
$$

\section{Pengujian Hipotesis Secara Parsial (t)}

Uji $\mathrm{t}$ atau parsial digunakan untuk menguji hipotesis apakah variabel bebas $\left(\mathrm{X}_{1}, \mathrm{X}_{2}\right)$ mempunyai pengaruh secara parsial terhadap variabel terikat. Dimana kriteria pengujian yang digunakan adalah:

Jika $\mathrm{t}_{\text {sig }}>\alpha=5 \%=0,05$ maka $\mathrm{H}_{0}$ ditolak

Jika $\mathrm{t}_{\text {sig }}<\alpha=5 \%=0,05$ maka Ha diterima

\section{Pengujian Hipotesis Secara Simultan (F)}

Uji $F$ pada dasarnya menunjukkan apakah semua variabel bebas yang dimasukkan dalam model mempunyai pengaruh secara bersamasama terhadap variabel terikat. Dimana kriteria pengujian yang digunakan adalah:

Jika $\mathrm{F}_{\text {sig }}>\alpha=5 \%=0,05$ maka $\mathrm{H}_{0}$ ditolak

Jika $\mathrm{F}_{\text {sig }}<\alpha=5 \%=0,05$ maka Ha diterima.

\section{Pengujian Koefisien Determinasi $\left(\mathbf{R}^{\mathbf{2}}\right)$}

Uji koefisien determinasi $\left(\mathrm{R}^{2}\right)$, pada intinya mengukur seberapa jauh kemampuan model dalam menerangkan variasi variabel terikat. Nilai koefisien determinasi adalah antara nol dan satu. Nilai $\mathrm{R}^{2}$ yang kecil berarti kemampuan variabel-variabel bebas dalam menjelaskan variasi terikat amat terbatas. Nilai yang mendekati satu berarti variabel-variabel bebas memberikan hampir semua informasi yang dibutuhkan variabel terikat..

\section{HASIL DAN PEMBAHASAN}

Dengan menggunakan bantuan software SPSS diperoleh hasil perhitungan yang dilakukan dalam tabel 1 koefisien regresi. Berdasarkan tabel 1 , maka diperoleh persamaan regresi linier berganda sebagai berikut: $\mathbf{Y}=\mathbf{2 , 8 8 3}+\mathbf{0 , 2 9 3 X _ { 1 }}+\mathbf{0 , 0 2 5 X _ { 2 }}$

1. Konstanta sebesar 2,883 menunjukkan nilai kinerja karyawan apabila kompensasi dan lingkungan kerja bernilai nol (tetap).
NIAGAWAN Vol 7 No 3 November 2018

2. Variabel kompensasi menunjukkan pengaruh yang positif terhadap kinerja karyawan sebesar 0,293. Jadi apabila kompensasi naik satu satuan maka kinerja karyawan akan meningkat sebesar 0,293 satuan dengan asumsi variabel lingkungan kerja tetap.

3. Variabel lingkungan kerja menunjukkan pengaruh yang positif dengan kinerja karyawan sebesar 0,025. Jadi apabila lingkungan kerja naik satu satuan maka kinerja karyawan akan meningkat sebesar 0,025 satuan dengan asumsi variabel kompensasi tetap.

Tabel 1

\begin{tabular}{|c|c|c|c|c|c|}
\hline \multirow{2}{*}{\multicolumn{2}{|c|}{ Model }} & \multicolumn{2}{|c|}{$\begin{array}{c}\text { Unstandardized } \\
\text { Coefficients }\end{array}$} & \multirow[b]{2}{*}{$\mathrm{t}$} & \multirow[b]{2}{*}{ Sig. } \\
\hline & & B & $\begin{array}{l}\text { Std. } \\
\text { Error }\end{array}$ & & \\
\hline \multirow{4}{*}{1} & (Constant) & 2.883 & .619 & 4.658 & .000 \\
\hline & Kompensasi(X1 & .293 & .104 & 2.831 & .008 \\
\hline & Lingkungan & - & & & \\
\hline & $\operatorname{Kerja}(x 2)$ & .025 & .163 & .151 & .881 \\
\hline
\end{tabular}

Koefisien Regresi Coefficients $^{\mathbf{a}}$

a. Dependent Variable: Kinerja Karyawan (Y) Sumber: Data Primer, diolah (2018)

Untuk mengetahui pengaruh secara parsial dari variabel bebas terhadap variabel terikat digunakan teknik analisis data dengan uji t. Berdasarkan tabel 1 diperoleh nilai uji $\mathrm{t}_{\text {sig }}$ setiap variabel bebas sebagai berikut :

a. Pengaruh Kompensasi terhadap Kinerja

Hasil nilai signifikansi sebesar 0,008 $<0,05$ maka hipotesis yang menyatakan kompensasi berpengaruh signifikan terhadap kinerja karyawan pada PT. Mopoli Raya Wilayah Timur Aceh Tamiang dapat diterima.

b. Pengaruh Lingkungan Kerja terhadap Kinerja Hasil nilai signifikansi sebesar 0,881>0,05 maka hipotesis yang menyatakan lingkungan kerja berpengaruh signifikan terhadap kinerja karyawan pada PT. Mopoli Raya Wilayah Timur Aceh Tamiang ditolak.

Untuk mengetahui pengaruh secara simultan dari variabel bebas terhadap variabel terikat digunakan teknik analisis data dengan uji $\mathrm{F}$. Berdasarkan tabel 2 diperoleh nilai uji $F_{\text {sig }}$ sebagai berikut : 
Tabel 2

ANOVA

ANOVA $^{a}$

\begin{tabular}{|ll|c|c|}
\hline & Model & F & Sig. \\
\hline \multirow{3}{*}{1} & Regression & 4.302 & $.023^{\mathrm{b}}$ \\
& $\begin{array}{l}\text { Residual } \\
\text { Total }\end{array}$ & & \\
\hline & Dependent & \multicolumn{2}{|c|}{ Variable: Kinerja }
\end{tabular}

Karyawan(Y)

b. Predictors: (Constant), Lingkungan Kerja(X2), Kompensasi(X1)

Dapat diketahui bahwa nilai $\mathrm{F}$ sig sebesar 0,023. Karena nilai F sig 0,023 < 0,05 maka dapat dinyatakan bahwa kompensasi dan lingkungan kerja secara simultan berpengaruh signifikan terhadap kinerja karyawan. Dengan demikian maka hipotesis dalam penelitian ini diterima.

Berdasarkan hasil pengolahan data dengan bantuan software SPSS diperoleh tabel Model Summary yang menunjukkan nilai $\mathrm{R}$ Square sebagai berikut:

Tabel 3

Model Summary

\begin{tabular}{|l|r|r|r|}
\hline Model & \multicolumn{1}{|c|}{$\mathrm{R}$} & \multicolumn{1}{c|}{ R Square } & Adjusted R Square \\
\hline 1 & $.472^{\mathrm{a}}$ & .223 & .171 \\
\hline
\end{tabular}

a. Predictors: (Constant), Kompensasi(X2), Lingkungan $\operatorname{Kerja}(X 1)$

Sumber: Data Primer, diolah (2018)

Dapat dilihat bahwa nilai $\mathrm{R}$ Square sebesar 0,223 . Hal ini berarti variabel kompensasi dan lingkungan kerja mempengaruhi kinerja karyawan pada PT. Mopoli Raya Wilayah Timur Aceh Tamiang sebesar 22,3\% sedangkan sisanya $77,7 \%$ dipengaruhi oleh variabel lain yang tidak diteliti dalam penelitian ini.

\section{KESIMPULAN DAN SARAN}

Berdasarkan hasil analisis data mengenai pengaruh kompensasi dan lingkungan kerja terhadap kinerja karyawan pada PT. Mopoli Raya Wilayah Timur Aceh Tamiang, maka dapat diperoleh beberapa kesimpulan antara lain sebagai berikut:

1. Diperoleh persamaan regresi linear berganda yaitu: $Y=2,883+0,293 X_{1}+\mathbf{0 , 0 2 5} X_{2}$. Artinya apabila tidak dipengaruhi oleh variabel kompensasi $\left(\mathrm{X}_{1}\right)$, lingkungan Kerja $\left(\mathrm{X}_{2}\right)$, maka kinerja karyawan (Y) pada PT
NIAGAWAN Vol 7 No 3 November 2018

Mopoli Raya sebesar 2,883. Dimana variabel kompensasi dan lingkungan kerja berpengaruh positif terhadap kinerja karyawan.

2. Variabel kompensasi dan lingkungan kerja mempengaruhi kinerja karyawan PT. Mopoli Raya Wilayah Timur Aceh Tamiang sebesar $22,3 \%$ dan sisanya sebesar $77,7 \%$ dipengaruhi oleh variabel lain yang tidak diteliti dalam penelitian ini.

3. Secara parsial menunjukkan bahwa variabel kompensasi sebesar $0,008<0,05$ maka hipotesis diterima, yang berarti bahwa kompensasi mempunyai pengaruh yang signifikan terhadap kinerja karyawan dan variabel lingkungan kerja sebesar 0,881 >0,05 maka hipotesis ditolak, yang berarti bahwa lingkungan kerja tidak mempunyai pengaruh signifikan terhadap kinerja karyawan pada PT. Mopoli Raya Wilayah Timur Aceh Tamiang.

4. Secara simultan menunjukkan bahwa $\mathrm{F}$ sig sebesar $0,023<0,05$, maka hipotesis diterima, yang berarti variabel kompensasi dan variabel lingkungan kerja secara bersama-sama mempunyai pengaruh yang signifikan terhadap kinerja karyawan

\section{REFERENSI}

Aprinawati , 2014, Pengaruh Kompensasi dan Iklim Organisasi terhadap Kinerja Karyawan Bagian tehnik pada PT. Perkebunan Nusantara III (Persero) Kebun Sei Dadap, Jurnal Quanomic, Vol. II No.01, Hal 1-10.

Bangun, W. 2012. Manajemen Sumber Daya Manusia. Erlangga: Jakarta.

Budianto dan Kartini. 2015. Pengaruh Lingkungan Kerja Terhadap Kinerja Pegawai Pada PT. Perusahaan Gas Negara (Persero) Tbk SBU Distribusi Jakarta. Jurnal Ilmiah Prodi Manajemen Universitas Pamulang. Vol 3, No. 1. Hal 100-124.

Firmandari, N. 2014. Pengaruh Kompensasi Terhadap Kinerja Karyawan Dengan Motivasi Kerja Sebagai Variabel Moderasi (Studi Pada Bank Syariah Mandiri Kantor Cabang Yogyakarta). EKBISI, Vol. IX, No. 1, hal. 25-34.

Ghozali, Imam. 2013. Aplikasi Analis Multivariate Dengan Program SPSS. Semarang: Badan Penerbit Univ. Diponogoro 
Hasibuan, Malayu S.P. 2014. Manajemen Sumber Daya Manusia. Jakarta: PT. Bumi Aksara.

Kuncoro, M., 2009, Metode Riset untuk Bisnis \& Ekonomi, Edisi ke tiga. Jakarta: PT. Gelora Aksara Pratama.

Leonardo Edrick dan Andreani Fransisca, 2015, Pengaruh Pemberian Kompensasi terhadap Kinerja Karyawan pada PT. Kopanitia, Jurnal Agora, Vol. 3 No.2, Hal 28-31.

Nitisemito, A.S. 2009. Manajemen Personalia. Jakarta: Graha Indonesia.

Nurcahyati, Wiwiet Eka, Rooswidjajani, dan Brimantyo, Harril. 2016. Pengaruh Kompensasi dan Lingkungan Kerja Terhadap Kinerja Karyawan (Studi Pada Karyawan Kontra Bagian Anodizing PT H.P. Metals Indonesia, Ngoro-Mojokerto, Jawa Timur. Jurna Bisnis dan Manajemen. Vol 3, No 2, Hal 17-24.

Panggabean, Mutiara S. 2010. Manajemen Sumber Daya Manusia. Bogor: Ghalia Indonesia.

Prasetiyo Actur, Ari Pradhanawati dan Widiartanto, 2014, Pengaruh Kompensasi, Motivasi Kerja dan Lingkungan Kerja terhadap kinerja Karyawan PT. Pelabuhan Indonesia III (Persero) Terminal Peti Kemas Semarang, Diponegoro Journal of Social and Politic, Vol. 2, No.3, Hal 1-9.

Rivai, Veithzal. 2009. Manajemen Sumber Daya Manusia Untuk Perusahaan. Jakarta: PT. Raja Grafindo Pers

Rukmini. 2017. Pengaruh Kompensasi dan Lingkungan Kerja terhadap Kinerja Karyawan pada CV. Roda Jati Karanganyar tahun 2016. Jurnal Akuntansi dan Pajak, Vol.17, No. 02, Hal 57-59.

Samsudin, Sadili. 2010. Manajemen Sumber Daya Manusia. Bandung: CV Pustaka Setia

Sedarmayanti. 2009. Sumber Daya Manusia dan Produktivitas Kerja. Bandung: CV Mandar Maju.

2011. Manajemen Sumber Daya Manusia. Bandung: Refika Aditama.

Simamora, H. 2009. Manajemen Sumber Daya Manusia. Yogyakarta: STIE YKPN.
NIAGAWAN Vol 7 No 3 November 2018

Sinuhaji, Marissa, 2013, Analisis Program Kompensasi terhadap Kinerja Karyawan (Studi Kasus padda Sales PT. Damco Indonesia), Skripsi, Universitas Sumatera Utara, Medan.

Suharyanto, dkk. 2014. Pengaruh Kompensasi dan Lingkungan Kerja terhadap Kinerja Karyawan Divisi QIP PT. GSI Cianjur. Jurnal Ilmiah Teknik Industri, Vol. 13, No. 2, Hal 195-200.

Surbakti. 2012. Analisis Pengaruh Kepemimpinan Transformasional dan Motivasi terhadap Kinerja Karyawan (Studi pada PT. Kereta Api Indonesia Daop IV Semarang). Jurnal Manajemen, Vol. 1. No. 3, Hal 1-16.

Sutrisno. E. 2011. Manajemen Sumber Daya Manusia. Jakarta: Kencana Primada Media Group. Kencana.

Sugiyono. 2011. Statistika Untuk Penelitian. Bandung: Alfabeta.

. 2016. Metode Penelitian Bisnis (Pendekatan Kuantitatif, Kualitatif dan R\&D). Bandung: Alfabeta.

Sunyoto, Danang. 2010. Uji Khi Kuadrat \& Regresi Untuk Penelitian, Yogyakarta: Graha Ilmu.

2012. Manajemen Sumber Daya Manusia. (1th ed). Yogyakarta: Center For Academic Publishing Service.

Wibowo. 2013. Perilaku Dalam Organisasi. Jakarta: Raja Grafindo Persada.

Wirawan. 2009. Evaluasi Kinerja Sumber Daya Manusia : Teori, Aplikasi dan Penelitian. Jakarta: Salemba Empat. 